\title{
Gastric cancer with lesion extending to spleen and perforation into free peritoneum
}

\author{
Roberto Gonçalves ${ }^{1 *}$, Roberto Saad JR², Carlos Alberto Malheiros ${ }^{2}$, Paulo Kassab ${ }^{2}$, Nathália Lins Pontes Vieira ${ }^{3}$ \\ ${ }^{1} \mathrm{MD}$, MSc. Department of Surgery, Faculdade de Ciências Médicas da Santa Casa de São Paulo (FCMSCSP), São Paulo, SP, Brazil \\ ${ }^{2} \mathrm{MD}$, PhD. Department of Surgery, FCMSCSP, São Paulo, SP, Brazil \\ ${ }^{3} \mathrm{MD}$. General Surgery Resident, Department of Surgery, FCMSCSP, São Paulo, SP, Brazil
}

Study conducted at the Department of Surgery, Faculdade de Ciências Médicas da Santa Casa de São Paulo (FCMSCSP), São Paulo, SP, Brazil

Article received: $11 / 8 / 2016$ Accepted for publication: $12 / 4 / 2016$

*Correspondence: Address: Rua Dr. Cesário Mota Júnior, 61 São Paulo, SP - Brazil Postal code: 01221-020 rgtorax@yahoo.com.br

\section{SUMMARY}

Perforated gastric carcinoma is a rare condition that is hard to diagnose preoperatively. It is associated with advanced cancer stages and has a high mortality, particularly in cases presenting preoperative shock. Few studies have investigated the presentation and adequate management of these carcinomas. In addition, there are no reports in the literature on perforations extending to the spleen, as described in this case, making the management of these lesions challenging. Our article reports a case of gastric tumor perforation extending to the spleen, which presented as a perforated acute abdomen. The patient was treated with total gastrectomy and D2 lymph node resection with splenectomy and progressed well with current survival of one year at disease stage IV.

Keywords: acute abdomen, hemoperitoneum, stomach neoplasms.

\section{INTRODUCTION}

Perforation of gastric cancer is a rare condition occurring in only $1 \%$ of gastric tumors and accounting for 10 to $16 \%$ of all perforations to this organ, with a mortality rate of up to $82 \%$. Cancer is generally not suspected in these cases because the majority of patients seeking emergency services have a picture consistent with acute perforated abdomen and diffuse peritoneal irritation. Intraoperative diagnosis remains challenging especially in services without freezing techniques for anatomopathological analysis..$^{1-3}$

Given the low incidence of cases and consequent scant studies, the optimal surgical treatment in these situations is not yet well defined. Full oncological resection can be hampered by the absence of pre or intraoperative diagnosis of the tumor.

\section{Case report}

A 54-year-old male patient with history of significant weight loss of $10 \mathrm{~kg}$ over the past two months presented to emergency services with intense abdominal pain and fainting 1 hour before. Physical examination revealed the patient to be thin, pale $(++/+++)$ and dehydrated $(++/+++)$. The abdomen was flat, painful on palpitation, tympanic on percussion in the right hypochondrium (Jobert's Sign) and there were signs of peritoneal irritation (abdominal muscular rigidity). This patient was diagnosed with a suspected acute perforated abdomen, and exploratory laparotomy was indicated.

The intraoperative finding was a tumor of the gastric floor with blockage and perforation of the spleen, and this also perforated the free peritoneum (Figures 1-3). A total gastrectomy including the spleen, large omentum and regional lymph nodes was performed. Reconstruction was achieved by Roux-en-Y jejunoesophageal anastomosis.

The anatomopathological exams revealed a moderately differentiated gastric adenocarcinoma contiguous to the hilar face of the spleen, affecting 7 of the 13 lymph nodes studied. Since no distal metastases were found, the patient was classified as stage IV. He was discharged on day 15 of the hospital stay and has been undergoing outpatient follow-up for one year.

\section{Discussion}

Perforation of gastric adenocarcinomas is rare. The patient in this case, akin to the majority of other cases described in the literature, presented at our emergency service with signs of perforated acute abdomen and no prior diagnosis of gastric neoplasia. The most commonly described signs and symptoms include abdominal pain and peritoneal irritation, which was the case of our patient. Recent studies have shown that only 15 to $30 \%$ of patients are diagnosed with neoplasia at a preoperative stage. ${ }^{1,2}$ The 


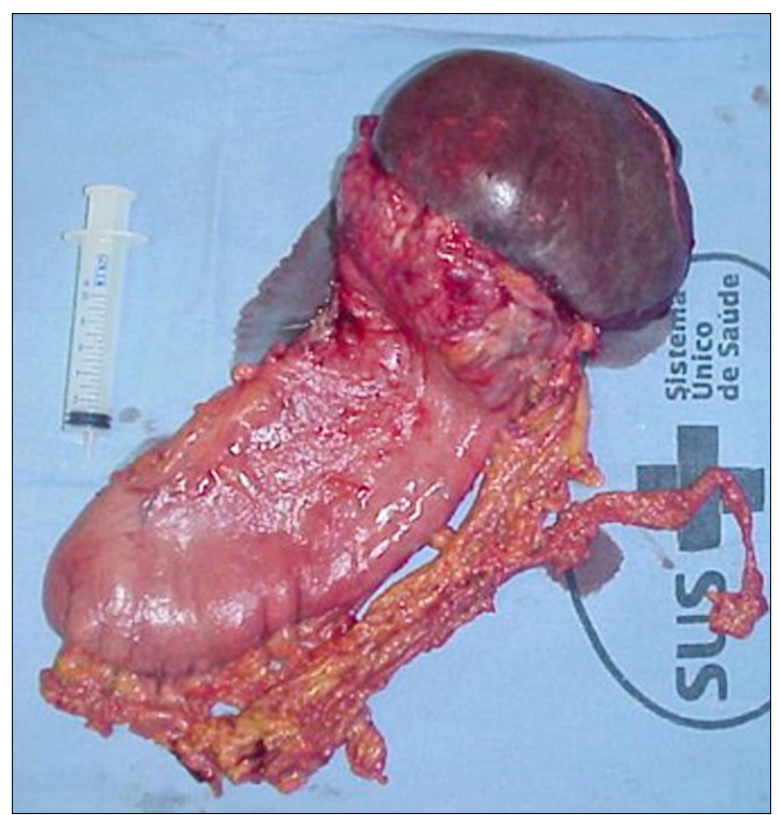

FIGURE 1 Surgical specimen of stomach and spleen, anterior view.

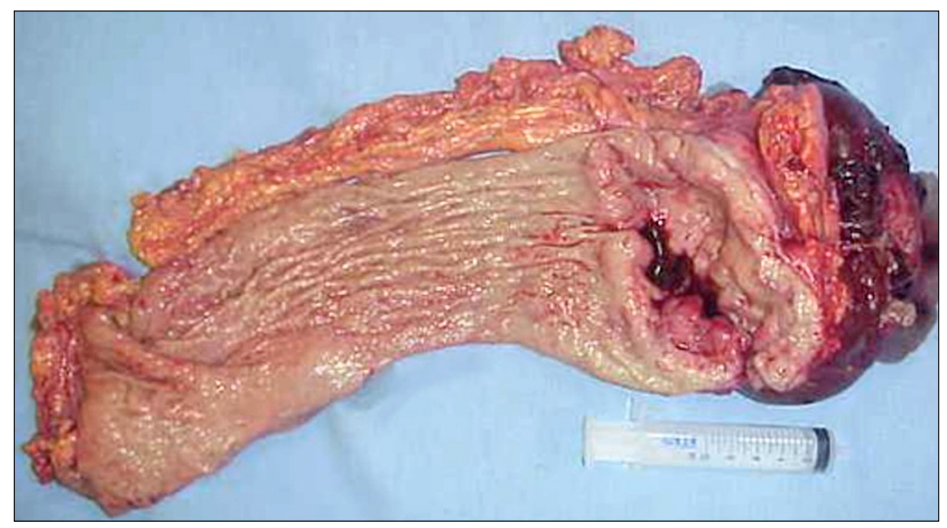

FIGURE 2 Surgical specimen of stomach and spleen, sagittal section.

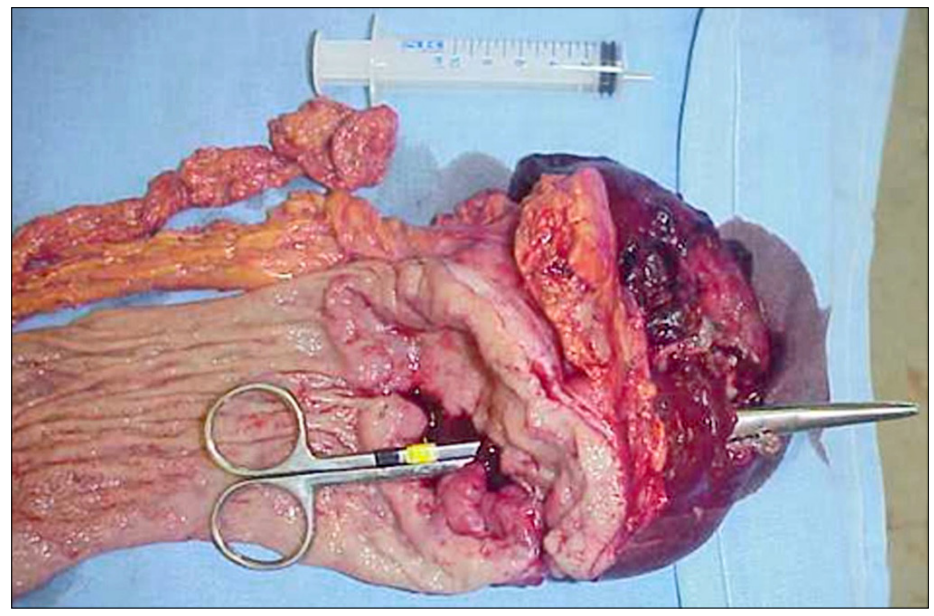

FIGURE 3 Surgical specimen of stomach and spleen, sagittal section showing gastric perforation contiguous to splenic perforation. 
only factor indicating suspected cancer is the patient's advanced age, which was not applicable to our case, diagnosed intraoperatively based on presentation suggestive of cancer with perforated lesion. ${ }^{1}$

Similarly to most studies in the literature, the reported case presented an advanced tumor with severe invasion and lymph node metastasis. ${ }^{1,2}$ However, there are no previous reports of a gastric perforation by adenocarcinoma progressing with splenic perforation. A literature search of the PubMed and Lilacs databases spanning 20 years with search words, gastric cancer, splenic perforation and perforated gastric cancer, found no case reports similar to that outlined above.

The spleen has a close relation with the stomach. The stomach floor, and the part proximal to its body, interfaces laterally with the spleen, increasing the likelihood of an extended lesion. ${ }^{4}$ However, the site of this patient's lesion, which was the gastric floor, is atypical according to the literature that reports that 50 to $80 \%$ of gastric perforations by cancer invade the distal third of the stomach. ${ }^{1-3,5}$

The optimal management of neoplastic lesions of the stomach complicated by perforation is not yet well-defined. The surgeon must be able to refrain the deleterious effects of the perforation, such as diffuse peritonitis and bleeding, and to provide curative correction or correction with a good prognosis for the patient. Given that the diagnosis of cancer is typically confirmed at the postoperative stage, full neoplastic resection is hampered. Moreover, most of the cases of perforation occur in advanced cancers with peritoneal dissemination. ${ }^{5}$ The most debated issue is whether the surgical treatment should comprise one or two operations, i.e. full resection in a single operation, or correction of the lesion in a first operation followed by oncological resection in a second. The current trend is to surgically manage these cases using two separate operations. ${ }^{1,2,5}$ In the present case, however, the patient underwent radical resection in a single surgical procedure, because neoplasia was suspected intraoperatively.

Another common debate regarding gastric cancers revolves around lymph node resection. Various Western and Japanese studies have sought to compare effectiveness in terms of mortality and morbidity among patients submitted to D1 (neoplastic tumor of up to $3 \mathrm{~cm}$ ) or D2 (up to $6 \mathrm{~cm}$ ) lymph node resection, the latter done without splenectomy or pancreatectomy. The result of these studies favors D2 resection, with splenectomy and pancreatectomy elected only in certain cases. ${ }^{6-8}$ In our patient, in addition to total gastrectomy and D2 lymph node resection, splenectomy was also carried out due to the organ's perforation. The patient presented N2 staging and the operation seems to have been curative.

The prognosis of patients with gastric tumor perforation depends on several factors but outcomes are poor in most cases. A study reviewing factors that contribute to poor prognosis showed that mortality is linked to advanced cancer stages. ${ }^{9}$ In very advanced cases, however, the only possible approach is that of simple suturing of the perforation, although patients undergoing this procedure have a higher mortality than those submitted to gastrectomy. ${ }^{10}$ There is no relation between perforation site and chances of survival. However, the study showed that preoperative shock and time until resolution of perforation were directly linked to mortality. ${ }^{9}$ Patients with advanced cancer are less able to deal with the complications of gastric perforation such as peritonitis and hemorrhage. Despite presenting advanced neoplasia in addition to the association with a splenic lesion, which may have led to bleeding and resultant shock, the patient progressed well, with current survival at one year. According to the literature, the 5 -year survival rate is $40 \%$ for emergency cases treated with total resection, which was the procedure performed in our patient. ${ }^{2}$

\section{Conclusion}

Exclusive perforated gastric carcinoma is per se a rare condition, and its association with splenic perforation has not yet been reported in the literature. The stage of the disease, presence of preoperative shock and time to surgical intervention are the main prognostic factors. Association with splenic lesion can aggravate bleeding, leading to shock and a poor outcome. Optimal management of this condition remains unclear and depends on surgeon skill and experience for a successful outcome.

\section{Conflict of interest}

The authors declare no conflict of interest.

\section{Resumo}

Neoplasia gástrica perfurada com extensão da lesão para o baço

A neoplasia gástrica perfurada é uma condição incomum e de difícil diagnóstico pré-operatório, estando relacionada a estágios avançados e com alta mortalidade, principalmente na presença de choque pré-operatório. Poucos estudos foram feitos quanto a sua forma de apresentação e ao tratamento adequado. Além disso, não há nenhum relato em literatura quanto à extensão da perfuração para 
o baço, como é descrito neste caso, tornando mais difícil a conduta. Este artigo relata um caso de perfuração de neoplasia gástrica com extensão para o baço, que se apresentou como abdome agudo perfurativo. Submetido a gastrectomia total e ressecção linfonodal D2 com esplenectomia, apresentou boa evolução e sobrevida atual de 1 ano, em um estadiamento IV da doença.

Palavras-chave: abome agudo, hemoperitônio, neoplasias gástricas.

\section{References}

1. Roviello F, Rossi S, Marrelli D, Manzoni G, Pedrazzani C, Morgagni P, et al. Perforated gastric carcinoma: a report of 10 cases and review of the literature. World J Surg Oncol. 2006; 4:19.

2. Kotan C, Sumer A, Baser M, Kiziltan R, Carparlar MA. An analysis of 13 patients with perforated gastric carcinoma: A surgeon's nightmare? World J Emerg Surg. 2008; 3:17.
3. Ergul E, Gozetlik EO. Emergency spontaneous gastric perforations: ulcus versus cancer. Langenbecks Arch Surg. 2009; 394(4):643-6.

4. Soybel DI. Anatomy and physiology of the stomach. Surg Clin North Am. 2005; 85(5):875-94.

5. Kasakura Y, Ajani JA, Fujii M, Mochizuki F, Takayama T. Management of perforated gastric carcinoma: a report of 16 cases and review of world literature. Am Surg. 2002; 68(5):434-40.

6. Cuschieri A, Weeden S, Fielding J, Bancewicz J, Craven J, Joypaul V, et al. Patient survival after D1 and D2 resections for gastric cancer: long-term results of MRC randomised surgical trial. Surgical Co-operative Group. Br J Cancer. 1999; 79(9-10):1522-30.

7. Ilias EJ, Malheiros CA, Kassab P, Castro OAP. Linfadenectomia no adenocarcinoma gástrico. Rev Assoc Med Bras. 2006; 52(4):270-4.

8. Toneto MG, Hoffmann A, Conte AF, Schambeck JPL, Ernani V, Souza HP. Linfadenectomia ampliada (D2) no tratamento do carcinoma gástrico: análise das complicações pós-operatórias. Rev Col Bras Cir. 2008; 35(4):229-34.

9. Ozmen MM, Zulfikaroglu B, Kece C, Aslar AK, Ozalp N, Koc M. Factors influencing mortality in spontaneous gastric tumour perforations. J Int Med Res. 2002; 30(2):180-4.

10. Gertsch P, Yip SKH, Chow LWC, Lauder IJ. Free perforation of gastric carcinoma. Results of surgical treatment. Arch Surg. 1995; 130(2):177-81. 